\title{
Evaluasi Rehabilitasi Hutan dan Lahan (RHL) di Daerah Aliran Sungai (DAS) Juwana pada Kawasan Gunung Muria Kabupaten Pati
}

\author{
Yohan Surtiani ${ }^{1}$, Lilin Budiati ${ }^{2}$
}

Diterima : 2 Januari 2015

Disetujui : 16 Januari 2015

\begin{abstract}
This research aims to develop a model program evaluation FLR at Juwana watershed area, especially the village of Mount Muria Klakahkasihan, Plukaran, Bageng, Sitiluhur Kingpin District of Pati regency and to review the position as a government agency responsible for RHL program. This study shows the percent achievement FRL programs in the watershed Juwana area of Mount Muria Pati regency of 65.8\%. The achievement consists of (1) a prerequisite Sustainable RHL Program Implementation (10\%), (2) management and protection of ecological resources (29\%), (3) sustainable forest production systems (4\%), (4) Increased participation and Socio-economic communities (34\%), (5) RHL Policy Implementation (23\%). The position of the Department of Forestry and Plantation institutions Pati regency in the position grow and build. Fore suggested Forestry and Plantation Pati regency make improvements FRL implementation strategy: (1) institutional strengthening, (2) development of networking and integration of programs and policies across sectors and organizations for the development of public services.
\end{abstract}

Key words : evaluation, forest and land rehabilitation, FRL , co-management, integrated watershed, stakeholders, institutional

\begin{abstract}
ABSTRAK
Penelitian ini bertujuan mengembangkan model evaluasi program RHL pada DAS Juwana Kawasan Gunung Muria khususnya Desa Klakahkasihan, Plukaran, Bageng, Sitiluhur Kecamatan Gembong Kabupaten Pati serta mengetahui posisi lembaga Dinas Kehutanan dan Perkebunan Kabupaten Pati sebagai lembaga pemerintah yang bertanggungjawab dalam program RHL. Penelitian ini menunjukkan persen capaian program RHL pada DAS Juwana Kawasan Gunung Muria Kabupaten Pati sebesar 65,8\%. Capaian tersebut terdiri dari (1) Prasyarat Pelaksanaan Program RHL Berkelanjutan (10\%), (2) Pengelolaan berbasis ekologi dan perlindungan Sumber Daya (29\%), (3) Sistem Produksi hutan lestari (4\%), (4) Peningkatan Partisipasi dan Sosial Ekonomi masyarakat (34\%), (5) Implementasi Kebijakan RHL (23\%). Posisi lembaga Dinas Kehutanan dan Perkebunan Kabupaten Pati berada pada posisi grow and build (pertumbuhan dan membangun). Disarankan kedepan Dinas Kehutanan dan Perkebunan Kabupaten Pati melakukan perbaikan strategi pelaksanaan RHL yaitu (1) Penguatan kelembagaan, (2) Pengembangan jejaring kerja dan integrasi program \& kebijakan lintas sektor dan lintas organisasi untuk pengembangan pelayanan publik.
\end{abstract}

Kata kunci : evaluasi, RHL, co-management, DAS terpadu, stakeholders, kelembagaan

\footnotetext{
${ }^{1}$ Dinas Kehutanan dan Perkebunan Kabupaten Pati

${ }^{2}$ Widyaiswara Provinsi Jawa Tengah, Dosen Luar Biasa Magister Pembangunan Wilayah dan Kota, Universitas Diponegoro

Kontak Penulis : yohansurtiani80@gmail.com
} 


\section{PENDAHULUAN}

Perencanaan pengembangan wilayah pada saat ini telah dihadapkan pada permasalahan dan tantangan tidak saja pada hal substantif perencanaan seperti tata ruang, pengembangan ekonomi, dan infrastruktur, tetapi juga memunculkan kebutuhan akan kelembagaan (institutions) yang memadai. Menurut North (1990) bahwa kelembagaan dalam hal ini mencakup tidak saja organisasi atau lembaga saja, melainkan juga aturan main (rule of the games), mekanisme koordinasi aktor yang terlibat beserta peran dan kontribusinya dalam proses pengambilan keputusan dan alokasi sumberdaya pembangunan pada skala wilayah dalam arti bagaimana tata kelola diaplikasikan dalam konteks pengembangan wilayah.

Sesuai dengan Undang Undang No 32 Tahun 2001 tentang Pemerintah Daerah yaitu adanya perubahan pola sentralistik menuju pola otonomi daerah (desentralisasi), bersama itu pula isu desentralisasi dan globalisasi mulai masuk dan berpengaruh dalam pengembangan wilayah pada akhirnya muncul kasus ketidakmampuan wilayah untuk mengatasi masalah yang bersifat antar daerah. Contoh permasalahan yang muncul sebagai salah satunya konflik pengelolaan wilayah adalah Kawasan Gunung Muria, secara administratif masuk dalam tiga Kabupaten (Pati, Jepara dan Kudus) dan mempunyai kebijakan masing-masing sebagai akibat desentralisasi dan otonomi daerah hal ini menjadikan permasalahan semakin kompleks. Faktor lain yang menjadikan kompleksnya masalah pengelolaan Kawasan gunung muria adalah wilayah yang relatif sempit sebagai daerah perlindungan sehingga rawan terhadap aktivitas perambahan yang menuju kepada kerusakan dan degradasi lingkungan. Banyaknya kepentingan di wilayah tersebut akan tetapi tidak ditunjang dengan pola kebijakan yang jelas tugas dan wewenang pengelolaan sesuai dengan konsep otonomi daerah yang ada. Kawasan Muria berada pada Daerah Aliran Sungai (DAS) Juwana yang menurut Keputusan Menteri Kehutanan No. 328/Menhut-II/2009 merupakan DAS Prioritas I dalam rangka Rencana Pembangunan Jangka Menengah (RPJM) tahun 2010 - 2014.

Menurut Budiati (2012) kosep dan indikator pembangunan berkelanjutan dalam pendekatan pengelolaan lingkungan pada saat ini adalah pendekatan pengelolaan lingkungan cenderung bersifat state-based (top down) dan community based (bottum up). Kedua pendekatan pengelolaan lingkungan tersebut bersifat dikotomis. Alternatif pendekatan pengelolan lingkungan oleh Niem chaipan \& Thallister (dalam Budiati, 2012) adalah pendekatan partisipatif (Collaborative Management) akan lebih memungkinkan terjadinya pertukaran gagasan (sharing idea), jalin kepentingan (knitting insterst) dan pemaduan karya (synergy of action) memberi kesempatan yang sama kepada masyarakat lokal dalam pelaksanaan kegiatan. Sehingga Collaborative-Management dianggap efektif dan mampu mengatasi permasalahan akibat pendekatan pengelolaan lingkungan.

Pola pembangunan wilayah yang pada saat ini telah mengalami ketidakseimbangan terutama pada aspek ekologi dengan aspek sosial dan ekonomi. Salah satu bukti ketimpangan tersebut adalah adanya kerusakan lingkungan akibat aktifitas sosial dan ekonomi yang berakibat kerusakan fungsi hutan dan lahan yang diidentifikasi sebagai lahan kritis. Kondisi kritis juga terjadi pada wilayah dengan fungsi penting yaitu fungsi perlindungan salah satunya adalah Kawasan Gunung Muria yang menurut Kepmenhut No. SK.359/Menhut-II/2004 mempunyai luas hutan baku 11.183,10 Ha dalam kawasan hutan dan 35.948 Ha di luar Kawasan Hutan dengan kondisi lahan kritis saat ini $11.203 \mathrm{Ha}$. Langkah penanganan yang telah dilakukan oleh pemerintah adalah dengan Rehabilitasi Hutan dan Lahan. 
Karakteristik kegiatan RHL yang kompleks dan bersifat jangka panjang menyebabkan program RHL membutuhkan evaluasi program yang perlu dilakukan dengan cermat, sistematis, dan menyeluruh, tidak hanya menggunakan sedikit indikator untuk menilai keberhasilannya. Keputusan Menteri Kehutanan dalam P.9/Menhut II/2013 pasal 44 menjelaskan bahwa hasil pekerjaan kegiatan penanaman RHL dapat diterima jika prosen tumbuh $\geq 60 \%$. Padahal jika dievaluasi kembali ukuran Persentase hidup tanaman, tinggi pohon, dan tingkat kesehatan tanaman hasil RHL, belumlah cukup untuk menggambarkan secara total tingkat keberhasilan kegiatan penanaman RHL mengingat dampak yang ditimbulkan jangka panjang dan kompleksitas kegiatan RHL sebagai sebuah sistem guna menunjang pembangunan wilayah yang berkelanjutan.

Permasalahan dampak pelaksanaan RHL menjadi lebih rumit karena RHL bersifat jangka panjang akan sangat penting untuk menjaga konsistensi pengambil kebijakan RHL dan penerapan kebijakan RHL tersebut dan Dinas Kehutanan dan perkebunan Kabupaten Pati sebagai penanggungjawab kegiatan RHL sampai saat ini belum menetapkan kriteria untuk melakukan evaluasi keberhasilan RHL lebih detail. Dampak program RHL tidak hanya ditujukan untuk perbaikan lingkungan tetapi diharapkan berpangaruh positif pada kondisi sosial ekonomi masyarakat sehingga dalam evaluasi capaian program RHL diperlukan ukuran lain yang mampu mengukur kompleksitas program RHL. Berdasarkan kondisi tersebut terdapat beberapa pertanyaan yang akhirnya mendasari penelitian ini, yaitu (1) Model evaluasi seperti apa dan variabel apa saja yang tepat untuk mengukur capaian program Rehabilitasi Hutan dan Lahan (RHL) pada Kawasan Gunung Muria? (2) Bagaimanakah posisi dan kondisi kelembagaan Dinas Kehutanan dan Perkebunan Kabupaten Pati sebagai penanggungjawab dan pelaksana program RHL?

\section{METODE PENELITIAN}

Penelitian ini menggunakan metode campuran (mix methode) yaitu metode kuantitatif melalui skala ranking prioritas yang diterapkan dari quisioner dan metode kualitatif melalui hasil wawancara narasumber (key person) atau observasi langsung di lapangan. Analisis yang dilakukan menggunakan pembobotan dengan AHP (Analisis Hierarchy Process) dan untuk mengetahui posisi kelembagaan Dinas pelaksana RHL dilakukan dengan Analisis Medan Daya (Force Field Analysis / FFA) dan Internal-External Strategic Factor Analyis Summary (IFAS-EFAS).

\section{GAMBARAN UMUM}

Kawasan Gunung Muria berada di wilayah Provinsi Jawa Tengah bagian utara-timur dengan posisi terletak pada derajat Lintang dan bujur 1100 dan 42'03" - 1100 01'57" BT dan 60 24'25" 60 47'15" LS dapat dilihat pada Gambar 1 dan Lokasi Penelitian ada di Desa Plukaran, Desa Klakahkasihan, Desa Sitiluhur \& Desa Bageng Kecamatan Gembong Kabupaten Pati DAS Juwana dapat dilihat pada Gambar 2. Luas wilayah sesuai Fungsi Kawasan Gunung muria dengan fungsi sebagai Hutan Lindung (HL), Hutan Produksi Terbatas (HPT) dan Hutan Produksi (HP) dapat dilihat pada Tabel 1.

Kawasan Gunung Muria merupakan Daerah Resapan Air (Recharge Area) yang penting bagi daerah bawahan di sekitarnya yang perlu di jaga bersama dan diselamatkan. Mengingat hanya wilayah yang relatif sempit yaitu $56.616,47$ Ha yang meliputi tiga Kabupaten yang berkelerengan rata-rata $25 \%$ - > $40 \%$ serta berfungsi sebagai daerah perlindungan sehingga 
rawan terhadap aktivitas perambahan yang menuju kepada kerusakan dan degradasi lingkungan.

Kondisi kawasan lindung pada saat ini mengalami kerusakan puncaknya yaitu terjadi pada awal masa reformasi yaitu tahun 2008. Menurut data Grand Design Kawasan Muria (2008) tercatat penyerobotan hutan lindung seluas $3.952,80 \mathrm{Ha}$ (Kudus 455,80 Ha, Jepara 2.874,50 Ha dan Pati $622,50 \mathrm{Ha}$ ). Penyerobotan tersebut dilakukan dengan menebang hutan lindung dan menggantinya dengan tanaman kopi, tanaman semusim tanpa perlakuan konservasi tanah yang baik. Tindakan perusakan lingkungan ini sangat memprihatinkan karena menyebabkan kerusakan yang berpotensi mengurangi kemampuan lahan untuk menampung air hujan sehingga menyebabkan erosi, limpasan dan tanah longsor.

TABEL 1

LUAS WILAYAH SESUAI FUNGSI KAWASAN GUNUNG MURIA

\begin{tabular}{|r|r|r|r|r|r|r|r|}
\hline \multirow{2}{*}{ Kabupaten } & Luas Baku & \multicolumn{6}{|c|}{ Fungsi Kawasan } \\
\cline { 5 - 8 } & $($ Ha) & HL (Ha) & $\%$ & $\begin{array}{r}\text { HPT } \\
(\text { Ha) }\end{array}$ & $\%$ & HP (Ha) & $\%$ \\
\hline Jepara & $6.619,30$ & $3.744,00$ & 57 & 825,40 & 12 & $2.049,90$ & 31 \\
\hline Pati & $2.632,40$ & $1.421,20$ & 54 & 923,20 & 35 & 288,00 & 11 \\
\hline Kudus & $1.931,40$ & $1.578,80$ & 82 & 303,40 & 16 & 49,10 & 3 \\
\hline Jumlah & $11.183,10$ & 6744,00 & 60 & $2.052,00$ & 18 & $2.387,00$ & 21 \\
\hline
\end{tabular}

Sumber : Grand Design Kawasan Muria,2008

Ket $: \mathrm{HL}=$ Hutan Lindung, $\mathrm{HPT}=$ Hutan Produksi Terbatas, HP = Hutan Produksi

Curah hujan di Kawasan Gunung Muria rata-rata > $3000 \mathrm{~mm} /$ th curah hujan berpotensi menyebabkan erosi dan banjir di bagian hilir yang menggenangi wilayah Kudus dan Pati yang terjadi pada Bulan Januari sampai Pebruari 2009 meredam 10 desa di Kabupaten Pati yaitu kecamatan Gabus, Jakenan, Kayen, Sokolilo karena luapan sungai Juana.

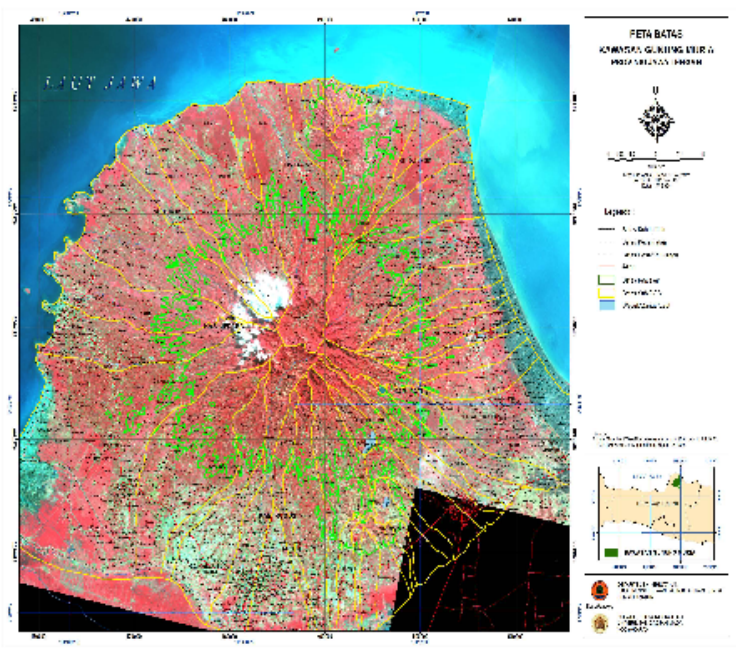

Sumber : Grand Design Kawasan Muria, 2008

GAMBAR 1

PETA BATAS KAWASAN GUNUNG MURIA

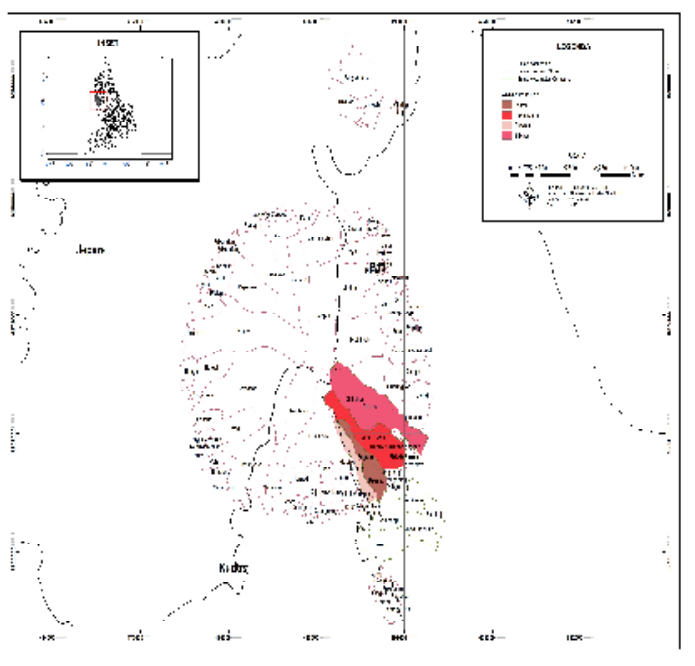

Sumber : Analisis, 2014

GAMBAR 2 PETA LOKASI PENELITIAN 
Bencana banjir pada DAS Juwana sangat dipengaruhi oleh lahan kritis. Hasil review lahan kritis tahun 2009 yang dilakukan oleh BP DAS Pemali Jratun mendapatkan data seperti pada Tabel 2.

TABEL 2

LUAS LAHAN KRITIS WILAYAH DAS JUWANA

\begin{tabular}{|c|c|c|c|c|c|c|c|}
\hline \multirow[b]{2}{*}{ No } & \multirow[b]{2}{*}{ Fungsi Kawasan } & \multicolumn{5}{|c|}{ Tingkat Kekritisan (Ha) } & \multirow[b]{2}{*}{$\begin{array}{r}\text { Jumlah } \\
\text { (Ha) }\end{array}$} \\
\hline & & $\begin{array}{l}\text { Agak } \\
\text { Kritis }\end{array}$ & Kritis & $\begin{array}{r}\text { Potensial } \\
\text { Kritis } \\
\end{array}$ & $\begin{array}{r}\text { Sangat } \\
\text { Kritis }\end{array}$ & $\begin{array}{l}\text { Tidak } \\
\text { Kritis }\end{array}$ & \\
\hline 1 & $\begin{array}{l}\text { Budidaya } \\
\text { Pertanian }\end{array}$ & 5.701 & 2.138 & 13.898 & 1.222 & 85.479 & 108.437 \\
\hline 2 & Hutan Lindung & 503 & 43 & 1129 & 6 & 356 & 2.038 \\
\hline 3 & Hutan Produksi & 946 & 1177 & 4523 & 224 & 10.548 & 17.418 \\
\hline 4 & Kawasan Lindung & 1.366 & 95 & 786 & 125 & 126 & 2.498 \\
\hline & Jumlah & 8516 & 3453 & 20336 & 1577 & 96510 & 130.638 \\
\hline
\end{tabular}

Sumber : Hasil Review Lahan Kritis, BP DAS Pemali Jratun, 2009
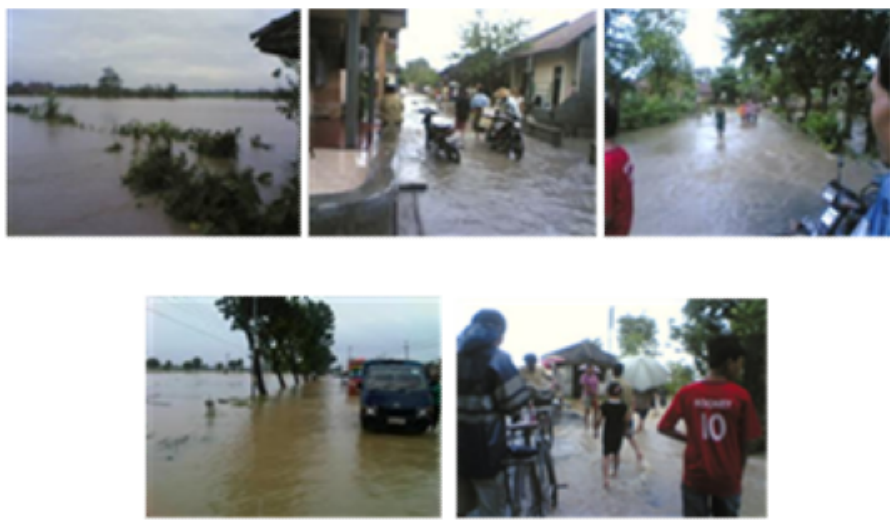

Sumber : Dinas Kehutanan dan Perkebunan Kabupaten Pati, 2013

GAMBAR 3

BANJIR KABUPATEN PATI DAN KUDUS TAHUN 2013

\section{KAJIAN TEORI EVALUASI PROGRAM REHABILITASI HUTAN DAN LAHAN (RHL) DI DAERAH ALIRAN SUNGAI (DAS) JUWANA PADA KAWASAN GUNUNG MURIA}

\section{Evaluasi}

Secara umum istilah evaluasi dapat disamakan dengan penaksiran (appraisal), pemberian angka (rating) dan penilaian (assessment). Dalam arti yang spesifik, evaluasi berkenaan dengan produksi informasi mengenai nilai atau manfaat hasil kebijakan. Menurut Dunn (1998) dikatakan bahwa kebijakan akan mempunyai nilai jika sudah mampu memberi hasil pada tujuan atau sasaran sehingga program telah mencapai tingkat kinerja yang bermakna.

\section{Pendekatan Pengelolaan Lingkungan}

Pendekatan pengelolaan lingkungan menggunakan dua konsep yaitu state-based dan community based (Budiati, 2012). Dua pendekatan ini, sebagaimana dikatakan beberapa ahli, cenderung merupakan pendekatan pengelolaan lingkungan yang berbasis pada aktor-aktor tunggal. Pendekatan state based cenderung bersifat top down (sentralis) dan beranggapan bahwa penduduk lokal tidak mempunyai kemampuan dalam sumber daya dan pengetahuan yang dibutuhkan, untuk memberikan kontribusi yang efektif dalam proses perencanaan, sedang pendekatan community based mempunyai beberapa kelemahan, yaitu; (1) lemahnya 
intitusi lokal ( terutama kurangnya mekanisme resolusi konflik), (2) keterbatasan informasi dan teknologi, (3) kurangnya system pendukung seperti informasi pasar, peningkatan kapasitas, technical assistance, fasilitas kredit dan kebijakan. Berdasarkan kelemahan-kelemahan pendekatan state based dan community based sebagaimana uraian diatas, muncul pendekatan kemitraan dan partisipasi (Collaborative Management).

Contoh produk pengelolaan Lingkungan yang sekarang dilaksanakan oleh pemerintah pusat dan pemerintah daerah yaitu Rehabilitasi hutan dan lahan (RHL). Penerapan program rehabilitasi telah dilakukan oleh Pemerintah sejak awal tahun 1950 an dengan berbagai pendekatan. Pada periode tahun 1980-1990-an kebijakan rehabilitasi hutan berada pada masa transisi dari top-down ke arah partisipatif. Untuk mengetahui nilai dan manfaat RHL maka perlu dilakukan ex-post Evaluation yaitu menilai efisiensi (keluaran dan hasil dibandingkan masukan), efektivitas (hasil dan dampak terhadap sasaran), ataupun manfaat (dampak terhadap kebutuhan) dari program RHL.

Feyerabend, Borrini, G., Farvar, M. T., Nguinguiri, J. C. \& Ndangang, V. A. 2000 menyatakan bahwa co-management merupakan suatu pendekatan yang pluralis untuk mengelola sumber daya alam secara multipihak dalam variasi peran untuk mencapai tujuan konservasi lingkungan, pemanfaatan sumberdaya alam yang berkelanjutan dan pembagian yang adil dalam manfaat dan tanggung jawab.

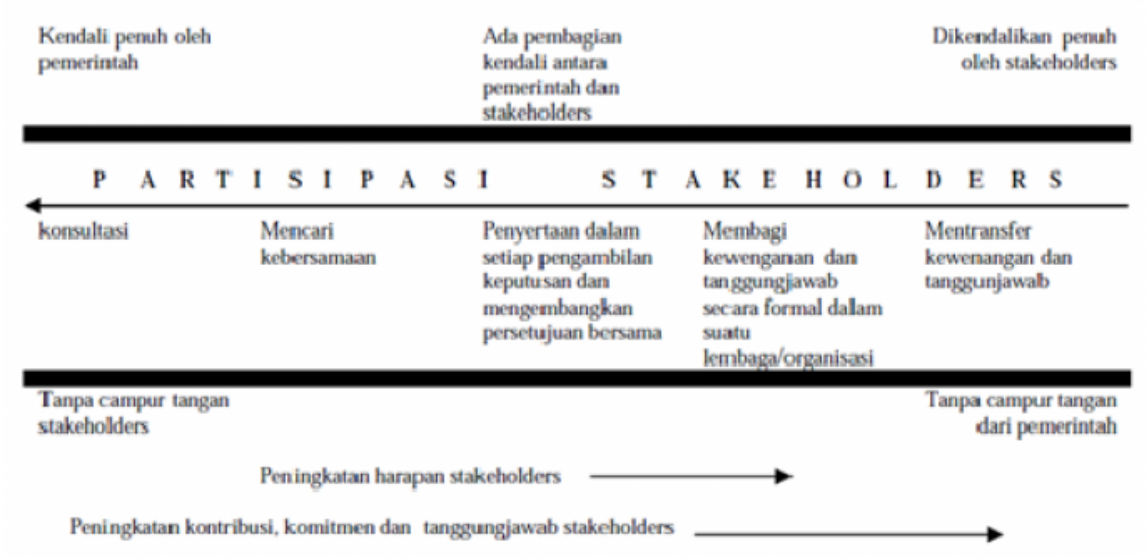

Sumber : Fayerabend et.al, 2000 dielaborasi oleh Yohan Surtiani, 2014

\section{GAMBAR 4 \\ TINGKATAN CO-MANAGEMENT FAYERABEND}

\section{Pengelolaan DAS Terpadu}

Prinsip-prinsip yang harus menjadi acuan dalam pengelolaan DAS Juwana secara terpadu adalah sebagai berikut : (a) Pengelolaan DAS Juwana dilakukan dengan memperlakukan DAS sebagai satu kesatuan ekosistem dari hulu sampai hilir, satu perencanaan dan satu sistem pengelolaan. Perencanaan bersifat terpadu dan Long term, (b) Pengelolaan DAS Juwana melibatkan multipihak, koordinatif holistik dan berkelanjutan, (c) Pengelolaan DAS Juwana bersifat adaptif terhadap perubahan kondisi yang dinamis sesuai dengan karakteristik DAS, (d) Pengelolaan DAS dilaksanakan dengan pembagian tugas dan fungsi, beban biaya dan manfaat antar multipihak secara adil, (e) Pengelolaaan DAS berdasar misi yang sejalan pada pemangku kepentingan (Nawir, Ani Adiwinata, dkk. 2008). 


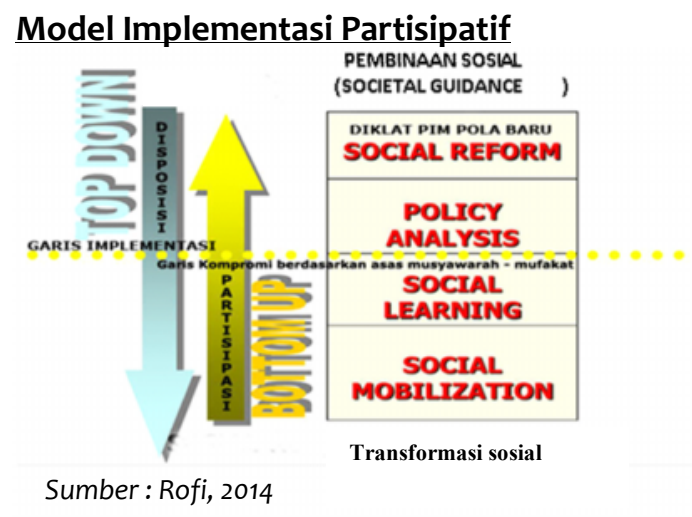

GAMBAR 5 MODEL IMPLEMENTASI PARTISIPATIF

Pembangunan wilayah berkelanjutan melalui strategi pembinaan sosial (social Guidance) yaitu untuk menggerakkan proses transformasi sosial (social transformation) berbasis komunitas aspirasi masyarakat yang muncul dari transformasi sosial tersebut dan dijadikan pertimbangan dalam analisis kebijakan (policy analisis) dan menyusun kebijakan (social Reform). Pada garis disposisi pemerintah dan garis partisipasi masyarakat akan bertemu pada garis kompromi yang merupakan wujud keterpaduan dan sinergi pemerintah dan masyarakat.

\section{Variabel Penelitian}

Kajian studi pustaka dan penelitian sebelumnya telah menghasilkan Variabel penelitian Evaluasi Program RHL di DAS Juwana pada Kawasan Gunung Muria yaitu sebagai berikut : (1) Prasayarat Pelaksanaan Program RHL Berkelanjutan, (2) Sistem Produksi hutan lestari, (3) Pengelolaan lahan berbasis ekologi \& perlindungan Sumber Daya, (4) Peningkatan Partisipasi \& Sosial Ekonomi masyarakat, (5) Implementasi Kebijakan RHL.

\section{ANALISIS EVALUASI PROGRAM REHABILITASI HUTAN DAN LAHAN (RHL) DI DAERAH ALIRAN SUNGAI (DAS) JUWANA PADA KAWASAN GUNUNG MURIA}

\section{Analisis Capaian Program Rehabilitasi Hutan dan Lahan}

Melalui tahap pembobotan dengan metode AHP dan perhitungan skor hasil wawancara dengan key person maka didapatkan capaian tiap variabel $\mathrm{RHL}$, dapat dilihat pada Tabel 3. Capaian Rehabilitasi Hutan dan Lahan (RHL) di Desa lokasi penelitian adalah 65,8\% menurut P.09/ Menhut II/ 2013 dikatakan dapat diterima atau berhasil karena $\geq 60 \%$. Persentase pencapaian dari paling tinggi ke yang paling rendah adalah : (1) Peningkatan partisipasi \& sosial ekonomi masyarakat 34\%, (2)Pengelolaan lahan berbasis ekologi dan perlindungan sumber daya (29\%), (3) implementasi kebijakan RHL (23\%), (4) prasyarat pelaksanaan program RHL berkelanjutan (10\%) dan (5) sistem produksi hutan lestari (4\%).

Tingkat partisipasi masyarakat dalam program RHL di Kawasan Gunung Muria sudah tercipta proses social learning dan social mobilization terbukti tingkat capaian sasaran peningkatan partisipasi \& sosial ekonomi masyarakat paling tinggi ( $34 \%$ ), jika kondisi ini dapat di lihat oleh pemerintah sebagai pemegang kebijakan maka akan dapat menjadi pola imlementasi kebijakan yang partisipatif. Menurut Rofi (2014), dikatakan bahwa model transformasi sosial akan menjadikan modal utama penentu kebijakan yang lebih adaptif untuk saat ini jika terjadi proses social mobilization,social learning pada tingkat masyarakat / buttom up (stakeholder pelaksana $\mathrm{RHL}$ ) dan pada disposisi top down (pemerintah) terjadi proses policy analysis dan social reform. Pertemuan kedua sisi top down (implementasi) dan buttom up dalam satu garis maka akan terjadi kompromi berdasar asas musyawarah mufakat. Pola pendekatan pengelolaan lingkungan dengan mengandalkan kekuatan partisipasi tersebut lebih dikenal dengan pola pembinaan sosial (Social Guidance) melalui reformasi sosial, sesuai dengan Gambar 7. 
TABEL 3

BOBOT SASARAN DAN KRITERIA EVALUASI PROGRAM RHL

\begin{tabular}{|c|c|c|c|}
\hline Variabel & $\begin{array}{r}\text { Bobot } \\
\text { standart }\end{array}$ & $\begin{array}{r}\text { Skor Hasil } \\
\text { capaian }\end{array}$ & $\begin{array}{l}\text { Persen } \\
\text { capaian }\end{array}$ \\
\hline $\begin{array}{r}\text { Prasayarat Pelaksanaan Program RHL } \\
\text { Berkelanjutan }\end{array}$ & 0.157 & 0.064 & $10 \%$ \\
\hline Sistem Produksi hutan lestari & 0.064 & 0.026 & $4 \%$ \\
\hline $\begin{array}{r}\text { Pengelolaan lahan berbasis ekologi \& } \\
\text { perlindungan Sumber Daya }\end{array}$ & 0.321 & 0.190 & $29 \%$ \\
\hline $\begin{array}{r}\text { Peningkatan Partisipasi \& Sosial Ekonomi } \\
\text { masyarakat }\end{array}$ & 0.244 & 0.226 & $34 \%$ \\
\hline Implementasi Kebijakan RHL & 0.215 & 0.153 & $23 \%$ \\
\hline JUMLAH & 1.000 & 0.658 & \\
\hline
\end{tabular}

Sumber : Analisis, 2014

Persen Capaian tertinggi hasil evaluasi didapatkan pada variabel Peningkatan Partisipasi dan sosial ekonomi masyarakat 34\%, dapat dijelaskan bahwa program RHL pada lokasi penelitian telah menunjukkan fakta bahwa partisipasi masyarakat sudah terjadi, indikator partisipasi masyarakat dalam implementasi RHL urut dari yang paling tinggi ke level paling rendah adalah level inisiatif program $16 \%$, pelaksanaan $15 \%$, alokasi sumber daya $14 \%$, pemantauan \& pengawasan $14 \%$, penggalian informasi $13 \%$ dan pengambilan keputusan $11 \%$. Pencapaian Variabel Partisipasi masyarakat dapat diuraikan dengan analisa pada Tabel 4 dan Gambar 6.

Tabel 4

CAPAIAN TINGKAT PARTISIPASI MASYARAKAT DALAM PROGRAM RHL

\begin{tabular}{|r|r|}
\hline Tingkatan Partisipasi & Persentase \\
\hline Inisiatif Program & 0.16 \\
\hline Penggalian Informasi & 0.13 \\
\hline Penggalian Keputusan & 0.11 \\
\hline Alokasi Sumber Daya & 0.14 \\
\hline Pelaksanaan & 0.15 \\
\hline Pemantauan \& pengawasan & 0.14 \\
\hline
\end{tabular}

Sumber : Analisis, 2014

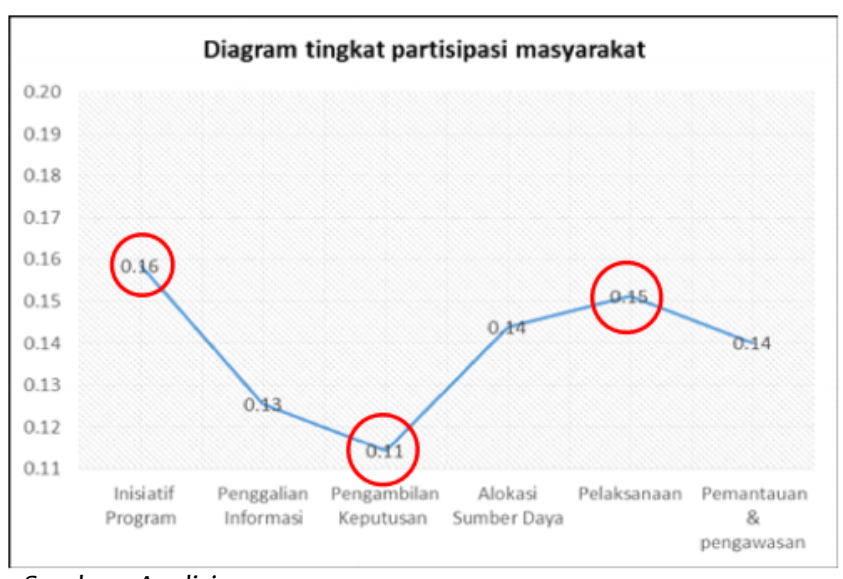

Sumber : Analisis, 2014 


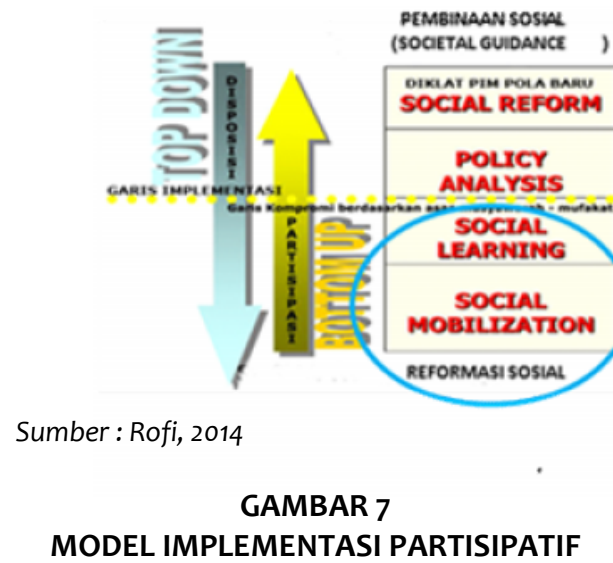

Data capaian tingkat partisipasi pada Tabel 5 dan Gambar 6 dapat menjelaskan fakta bahwa pada program RHL sudah terjadi reformasi sosial dengan ditandai tingkat partisipasi masyarakat pada tingkat inisiatif program dan pelaksanaan yang tinggi, akan tetapi dalam pengambilan keputusan masih berada dipihak pemerintah atau partisipasi masyarakat rendah sehingga dalam Model Implementasi Partisipatis seperti Gambar 7 tidak terjadi pembagian tanggung jawab / kewenangan maka tidak tercapai titik kompomi antara pemerintah dan masyarakat, mengakibatkan prosen pencapaian RHL masih rendah.

Hasil penelitian tersebut jika dikaitkan dengan spektrum tingkatan co-management Fayerabend et.al (2000) maka tingkat partisipasi masyarakat berada pada spektrum pembagian kendali antara pemerintah dan stakeholder tepatnya diantara spektrum mencari kebersamaan dan pernyataan dalam setiap pengambilan keputusan serta mengembangkan tujuan bersama. Kondisi tersebut terlihat pada Gambar 8.

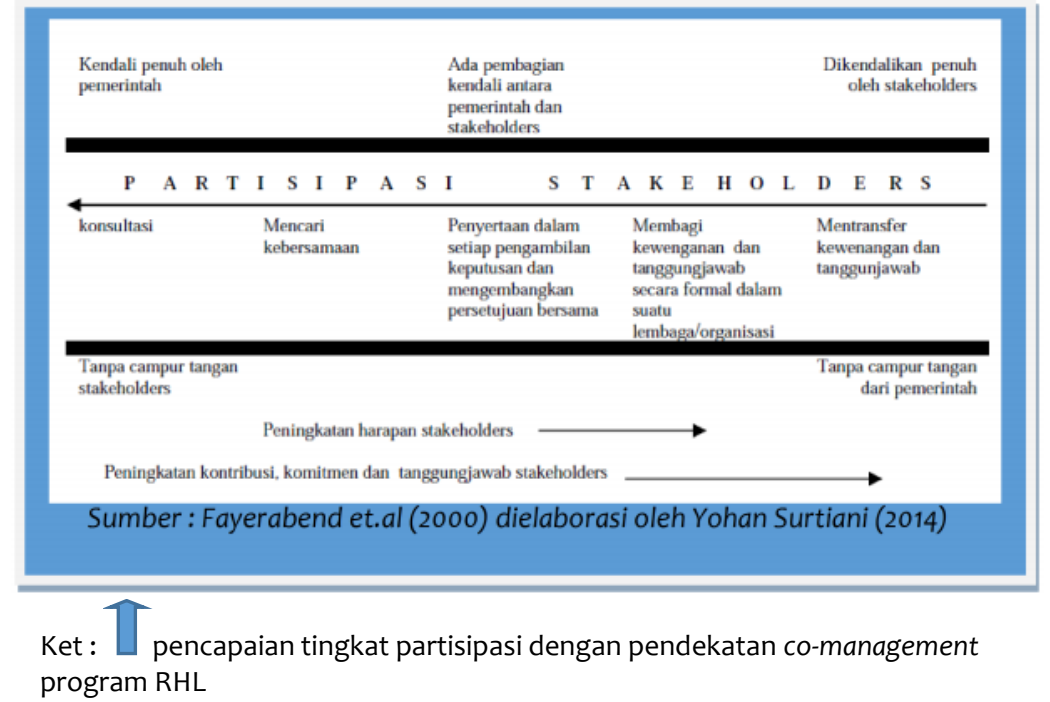

GAMBAR 8

TINGKAT PARTISIPASI CO MANAGEMENT FAYERABEND

Tingkat partisipasi yang tinggi jika terwadahi dan mendapatkan fasilitas dari pemerintah maka akan dapat menjadi modal dalam perubahan pola kegiatan baru yang berbasis pada kepentingan bersama. Adanya pembagian kendali antara pemerintah dan stakeholder akan mempermudah dalam pelaksanaan program RHL.

\section{Analisis Stakeholder dan Kelembagaan Program Rehabilitasi Hutan dan Lahan}

Analisis Stakeholder

Stakeholder adalah orang, kelompok atau institusi yang berkepentingan terhadap suatu proyek atau program. Keberhasilan implementasi Rehabilitasi Hutan dan Lahan (RHL) tidak 
dapat mengabaikan stakeholder dengan tingkat kapasitas lembaganya. Penelitian ini akan melakukan proses identifikasi stakeholder dan mengetahui tingkat kepentingan mereka. Hasil analisis diskripsi indikator penilaian kekuatan pengaruh stakeholder pelaksanaan kegiatan Rehabilitasi Hutan dan Lahan di Kawasan Gunung Muria Kabupaten Pati didapatkan Matrik Kekuatan Pengaruh stakeholder seperti pada Tabel 5 dan peringkat stakeholder tergambar pada Gambar 9.

TABEL 5

MATRIKS KEKUATAN PENGARUH STAKEHOLDER

\begin{tabular}{|c|c|c|c|c|c|}
\hline \multirow[b]{2}{*}{ No. } & \multirow[b]{2}{*}{ Stakeholder } & Power & $\begin{array}{c}\text { Proximit } \\
y\end{array}$ & Urgency & \multirow[b]{2}{*}{ Skor } \\
\hline & & $\begin{array}{l}\text { (Keku } \\
\text { atan) }\end{array}$ & $\begin{array}{c}\text { (Keterlib } \\
\text { atan) }\end{array}$ & $\begin{array}{c}\text { (Tingkat } \\
\text { kekritisa } \\
\text { n) }\end{array}$ & \\
\hline 1 & Pimpinan Daerah : Bupati & 4 & 1 & 3 & 8 \\
\hline 2 & Dinas Kehutanan dan Perkebunan & 3 & 4 & 4 & 11 \\
\hline 3 & DPRD Pusat, Provinsi \& Kabupaten & 2 & 2 & 3 & 7 \\
\hline 4 & $\begin{array}{l}\text { Bappeda Provinsi Jawa tengah, BLH Prov.Jateng,Dinas } \\
\text { Kehutanan Provinsi Jateng }\end{array}$ & 3 & 4 & 4 & 11 \\
\hline 5 & Kementrian Kehutanan -(BP DAS Pemali Jratun) & 4 & 4 & 4 & 12 \\
\hline 6 & Dinas Pertanian, BLH Kab Pati,Bappeda Kab Pati,Perhutani & 2 & 2 & 3 & 7 \\
\hline 7 & Kelompok Tani Sido Makmur (Plukaran) & 2 & 3 & 4 & 9 \\
\hline 8 & Forum Komunikasi Kawasan Muria (FGD) & 1 & 2 & 3 & 6 \\
\hline 9 & Corporate Social Responsibility (CSR) : PT Dua Kelinci, Bank BRI & 1 & 1 & 1 & 3 \\
\hline 10 & LSM : LP2S & 1 & 3 & 3 & 7 \\
\hline 11 & $\begin{array}{l}\text { Media informasi : Media Kompas, Web Site Dinas/instansi BP } \\
\text { DAS PJ,Bappeda,Dishutbun Pati }\end{array}$ & 1 & 1 & 3 & 5 \\
\hline 12 & Universitas Muria Kudus/ Muria Reseach Center (MRC) & 1 & 3 & 4 & 8 \\
\hline 13 & Masyarakat Umum & 1 & 2 & 3 & 6 \\
\hline 14 & Perusahaan BUMN (Perhutani,PTPN Jollong) & 1 & 2 & 3 & 6 \\
\hline
\end{tabular}

Sumber : Analisis, 2014 dan Walker et.a,l, 2008

Keterangan : skoring berdasar tabel 1.2

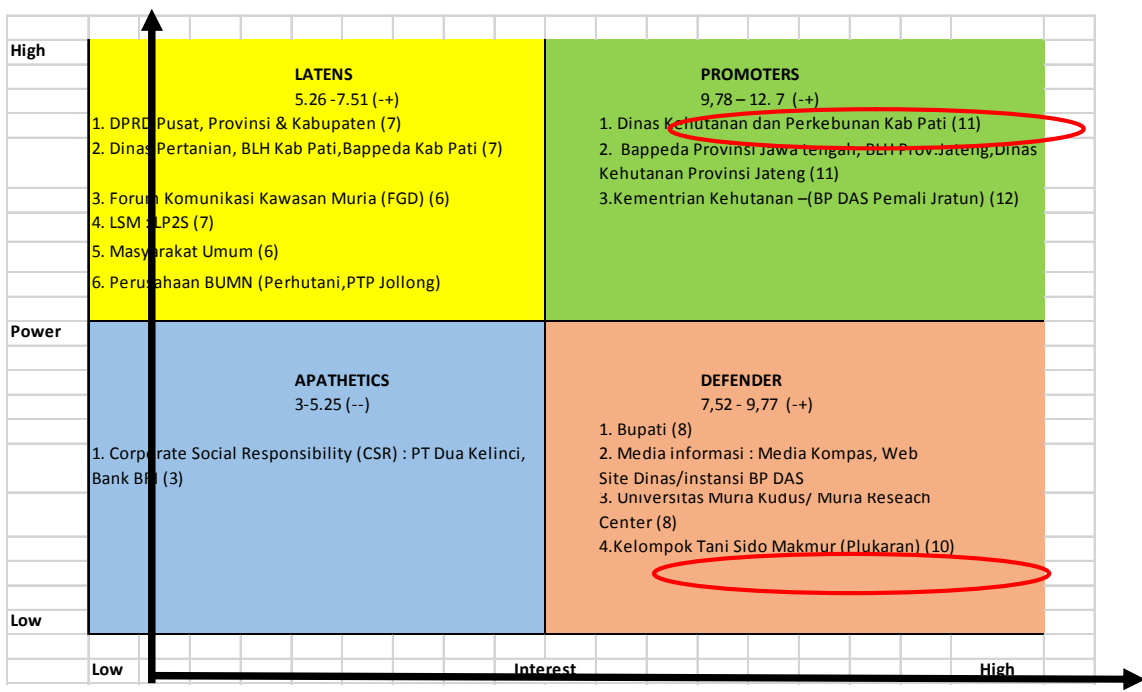

Sumber : Analisis, 2014

GAMBAR 9

DIAGRAM PERINGKAT STAKEHOLDER

PROGRAM REHABILITASI HUTAN DAN LAHAN KAWASAN GUNUNG MURIA 
Posisi stakeholder Dinas Kehutanan dan Perkebunan high power, high interest terletak pada kwadran Promoters. Tingkat partisipasi masyarakat tinggi (high interest), Low power terletak pada kwadran Defender dan kenyataannya Kelompok Tani pelaksana program RHL tidak terlibat dalam pengambilan keputusan sehingga secara konseptual bahwa program RHL terletak pada spekturm kendali masih ada pada pemerintah (sharing authority lemah) menyebabkan capaian RHL menjadi rendah.

\section{Analisis Kelembagaan}

Pada analisis medan daya (Force Field analysis/FFA) didapatkan total skor faktor pendorong lebih besar daripada faktor penghambat sehingga program RHL masih layak dan mampu untuk dilaksanakan oleh Dinas Kehutanan dan Perkebunan. Hasil analisis pada Gambar 10 dan Gambar 11.
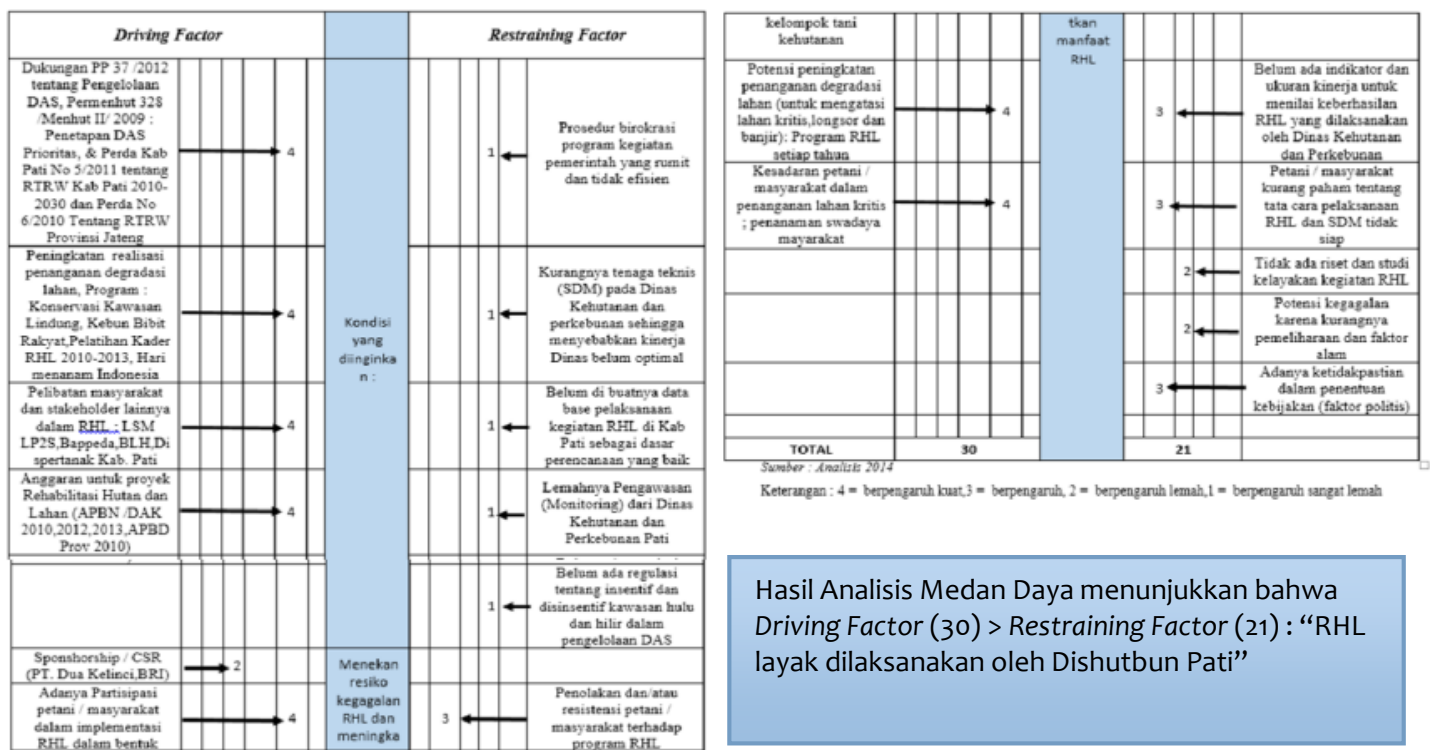

Hasil Analisis Medan Daya menunjukkan bahwa Driving Factor (30) > Restraining Factor (21) : "RHL layak dilaksanakan oleh Dishutbun Pati"

Sumber : Analisis, 2014

\section{GAMBAR 10 \\ HASIL ANALISIS MEDAN DAYA TERHADAP KELAYAKAN KEGIATAN RHL PADA KAWASAN GUNUNG MURIA}

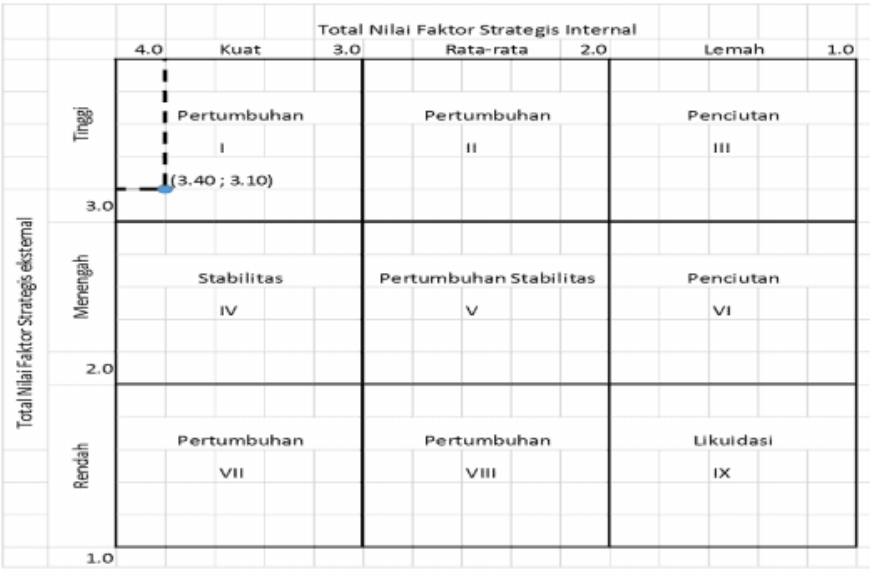

Dinas Kehutanan dan Perkebunan Kabupaten Pati dalam Implementasi Rehabilitasi Hutan dan Lahan adalah pada Sel I yang artinya berada dalam keadaan "pertumbuhan dan membangun" (grow and build)

Sumber : Analisis, 2014 dan Wheelen \& Hungger (dalam Agus Wuryato, 2014)

GAMBAR 11 


\section{KESIMPULAN}

Model evaluasi dengan menggunakan multikriteria dan variabel dengan pendekatan collaboretive management dan pengelolaan DAS terpadu sangat tepat untuk mengevaluasi keberhasilan RHL pada DAS Juwana Kawasan Gunung Muria dengan hasil evaluasi tercapai 65,8\%, yang berarti menurut standart P.03 / Menhut II / 2013 bahwa program RHL berhasil ( $\geq 60$ \%) terdiri dari rincian sebagai berikut : (1) Peningkatan Partisipasi \& Sosial Ekonomi masyarakat (34\%) , (2) Pengelolaan berbasis ekologi \& perlindungan Sumber Daya (29\%), (3) Implementasi Kebijakan RHL (23\%), (4) Prasayarat Pelaksanaan Program RHL Berkelanjutan (10\%) dan (5) Sistem Produksi hutan lestari (4\%). Jika pencapaian keberhasilan RHL masih belum maksimal $(65,8 \%)$ adalah disebabkan pada spekturm kendali kegiatan masih ada pada pemerintah ( share authority lemah), pemerintah berada pada jenis stakeholder promoter (high interest dan high power) sedang masyarakat pelaksana RHL termasuk pada jenis stakeholder defender (hight interset dan low power). Posisi organisasi Dinas Kehutanan dan Perkebunan Kabupaten Pati sebagai pelaksana RHL di DAS Juwana Kawasan Gunung Muria Kabupaten Pati ada pada posisi "pertumbuhan dan membangun" (grow and build).

\section{DAFTAR PUSTAKA}

BP DAS Pemali Jratun. 2009. Review Lahan Kritis di Wilayah Balai Pengelolaan DAS Pemali Jratun Tahun. Semarang.

Budiati, Lilin. 2012. Good Governance Dalam Pengelolaan Lingkungan Hidup. Bogor: Ghalia.

Feyerabend, Borrini, G., Farvar, M. T., Nguinguiri, J. C. \& Ndangang, V. A. 2000. Co-management of Natural Resources: Organising, Negotiating and Learning-by-Doing. Germany: GTZ and IUCN, Kasparek Verlag, Heidelberg.

Keputusan Menteri Kehutanan No. SK.359/Menhut-II/2004 tentang Perubahan Keputusan Menteri Kehutanan dan Perkebunan Nomor 435/Kpts-li/1999 Tanggal 15 Juni 1999 Tentang Penunjukan Kawasan Hutan di Wilayah Provinsi Jawa Tengah.

Nawir, Ani Adiwinata, dkk. 2008. Rehabilitasi Hutan di Indonesia: Akan Kemanakan Arahnya Setelah Lebih dari Tiga Dasa Warsa. Bogor: Center for International Forestry Research (CIFOR).

North Dauglass C. 1990. Institution Change and Economic Performance. New York: Cambridge University Press.

Peraturan Menteri Kehutanan Republik Indonesia Nomor: P.9/Menhut-II/2013 Tentang Tata Cara Pelaksanaan, Kegiatan Pendukung dan Pemberian Insentif Kegiatan Rehabilitasi Hutan dan Lahan.

Rofi, Moh. 2014. Menuju Penataan Wonosobo yang Partisipatif dan Berkeadilan. Rumah Tata Ruang. Pemerintah Kabupaten Wonosobo

Saaty, Thomas L. 1991. Decision Making Fir Leader the Analytical Hierarchy Process for Decisions in Complex World. University of Pitsburgh.

Walker, Derek, Stave Rowlinson. 2008. Procurement System: A Cross-Industry Project Management Perspective. Routledge.

Wuryanto, Agus. 2014. Sistem Pemungutan, Pembayaran dan Tata Kelola (P2TK) Pajak Daerah online (e-Tax). Kota Semarang. 